\title{
Evaluation method for building performance in Light Wood Frame in Brazil
}

\author{
Método para avaliação de desempenho de edificações em \\ Light Wood Frame no Brasil
}

\begin{abstract}
Nicolle Christine Sotsek
Drielle Sanchez Leitner

Bruno Lacerda Santos

Janilce dos Santos Negrão Messias

Adriana de Paula Lacerda Santos

${ }^{1}$ Nicolle Christine Sotsek 1Universidade Federal do Paraná Curitiba - PR - Brasil

${ }^{2}$ Drielle Sanchez Leitner Universidade Federal do Paraná Curitiba - PR - Brasil

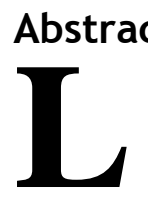

ight wood frame (LWF) is a construction system considered innovative in Latin American countries, which has been used as a strategy to mitigate housing deficits. Since this construction system is new in these countries, a rigorous assessment of their manufacturing, construction and use is essential. Thus, this research aims to develop a method to evaluate the performance of LWF buildings in Brazil to help builders optimise the construction system in the country. The study made use of the literature to identify valuable criteria for a building performance evaluation using qualitative tools, such as questionnaires and the Delphi technique, to select specific criteria for the LWF system. Finally, statistic tools, criteria groups and weights were generated. As a result, the study established a framework with 5 dimensions, 19 criteria and 41 sub-criteria, thus understanding which the most important criteria are to be evaluated during the LWF building performance evaluation. Finally, the criteria with the highest scores refer to structural durability, maintenance, sealing and control of thermal, acoustic, visual and air quality comfort.

Keywords: Light Wood Frame. Building performance. Evaluation method of building performance.

\section{Resumo}

O light wood frame (LWF) é um sistema construtivo considerado inovador em países latino-americanos e tem sido utilizado como estratégia para combate do déficit habitacional. Uma vez que o sistema construtivo é novo nesses países, é essencial uma rigorosa avaliação da sua fabricação, construção e utilização. Desta forma, esta pesquisa tem como objetivo elaborar um método de avaliação de desempenho de edificações em LWF no Brasil que permita auxiliar as construtoras a potencializar o sistema construtivo no país. $O$ estudo utiliza a literatura para identificação dos critérios que devem ser avaliados durante uma análise de desempenho de uma edificação, emprega ferramentas qualitativas, tais como questionário e a técnica Delphi, para selecionar os critérios específicos para o sistema LWF, e por fim, utiliza ferramentas estatísticas para agrupar os critérios e gerar pesos. Como resultado, a pesquisa estabeleceu um quadro com 5 dimensões, 19 critérios e 41 subcritérios, entendendo assim quais são os critérios mais importantes a serem avaliados durante a avaliação do desempenho de uma edificação LWF. Por fim, os critérios com maior pontuação fazem referência à durabilidade estrutural, manutenção, vedações e controle de conforto térmico, acústico, visual e de qualidade do ar.

${ }^{5}$ Adriana de Paula Lacerda

Santos

${ }^{5}$ Universidade Federal do Paran Curitiba - PR - Brasil
\end{abstract}

Recebido em 06/12/18 Aceito em 08/01/20

Palavras-chave: Light Wood Frame. Desempenho de edificações. Método de avaliação de desempenho de edificações. 


\section{Introduction}

The performance evaluation of buildings is highly important in the effort to improve social housing (BONNATO; MIRON; FORMOSO, 2011). The search for better performance results for these construction partnerships, besides generating benefits for its users, also contributes to improving society (INSTITUTO..., 2007). Construction companies that use LWF are attempting to fill this market niche. They target appropriate solutions that meet the requirements set by current regulations but must also be cost-effective to remain within the limited budget. Considering that LWF is a new construction system in Brazil, a rigorous evaluation of its manufacturing, construction and use is essential. It is important to emphasise that any foreign technology incorporated in the country must be analysed with caution, especially when the construction system does not have a specific standard, such as LWF in Brazil.

Therefore, the objective of the present study is to propose an evaluation method for the performance of LWF buildings focusing on social housing. It aims to establish specific criteria for the construction system and propose a performance standard for this category of buildings in Brazil. Studies involving performance evaluation in innovative construction systems are necessary to present the results to corporate businesses, contributing to the system's market dissemination. Additionally, such studies help to obtain building permits or contracts, such as the "Minha Casa, Minha Vida" (My House, My Life) Program for social housing, which must comply with the current performance and quality standards.

Numerous studies in the literature propose developing evaluation methods for the performance of buildings, but none of them is specific for LWF buildings in Brazil. In addition, according to Riratanaphong and van der Voordt (2015), knowledge regarding the performance of buildings worldwide is quite limited.

The studies identified presented evaluation methods for the performance of specific buildings, such as dwellings (IBEM et al., 2013; HASHIM; AKSAH; SAID, 2012; NIK-MAT; KAMARUZZAMAN; PITT, 2011; MOHIT; AZIM, 2012; MOHIT; NAZYDDAH, 2011), commercial buildings (LAI; MAN, 2017), buildings in the healthcare sector (STEINKE; WEBSTER; FONTAINE, 2010; TALIB; YANG; RAJAGOPALAN, 2013), and education (KHALIL; KAMARUZZAMAN; BAHARUM, 2016; KHAN; KOTHARKAR, 2012; NAZEER; DE SILVA, 2016) among others to evaluate a wide range of constructions (GOPIKRISHNAN; TOPKAR, 2017; STØRE-VALEN; LOHNE, 2016; LAVY; GARCIA; DIXIT, 2010). However, no studies focusing on the evaluation of popular housing using the LWF system were found.

In addition, most of the studies found in the literature analysed buildings made in Western and Nordic countries. According to Nazeer and De Silva (2016), there are no in-depth studies about performance evaluation of buildings in tropical countries.

Therefore, the main objectives of this research regarding the method are:

(a) define a set of criteria and sub-criteria to evaluate the performance of LWF buildings in Brazil; and

(b) quantify and evaluate these criteria and sub-criteria in order to establish weights and rank among them according to their degree of importance.

\section{Performance of buildings}

For more than 40 years, the concept of building performance has been studied worldwide and has been understood as the behaviour in the use of buildings throughout their service lives (BLACHERE, 1974). Khalil, Kamaruzzaman and Baharum (2016) complete the concept signalling that performance is the maximum efficiency capacity of a building over its service life. Service life is understood as a period of time during which the building maintains the expected performance, when submitted only to maintenance activities predefined in its design, as established in the NBR 15575 standard, by the Brazilian Association of Technical Standards (ABNT, 2013).

In addition to the conceptual discussion, the greatest challenge of building performance is to translate users' needs into requirements and criteria that can be objectively measured, to evaluate the physical characteristics of the facilities and services through inspection prototypes, on-site measurements, laboratory tests, etc. Furthermore, subjective measures should be included such as perception, satisfaction and aspirations of the users and/or building construction technical team using questionnaires and interviews (NURIZAN; HASHIM, 2001).

In order to meet the requirements of health, safety, well-being and convenience for users, worldwide regulatory building systems have been created (BORGES, 2008). These systems are generally made by 
controlling the design, construction and operation phases and can be based on certifications, audits and other types of inspection. In Brazil, the current regulatory system is the NBR 15575 standard (ABNT, 2013), which governs the performance of all residential buildings of up to five floors.

However, to provide the maximum operation of the buildings and to improve their efficiency, regular and continuous performance evaluation is essential. The term currently used for this systematic process is Building Performance Evaluation (BPE), which combines the objectives of the client with the performance criteria established by specialists in order to measure the degree of satisfaction and performance of a building for those users (PREISER, 1995).

This process, according to Preiser (1995), is based on feedback and evaluation of all construction phases, from strategic planning and scheduling, design, construction, pre-occupancy and post-occupancy to adaptation, reuse or recycling, that is, this process analyses construction throughout the entire life cycle.

Ongoing evaluations can be conceptualized as "feed forward best practices", meaning the lessons learned from one construction project are "fed" into the next project. This cycle continues in order to generate a database of previous constructions, and this base, in turn, helps to make better decisions and designs.

Thus, BPE serves as a tool that adds value, assisting managers in decision making at strategic and operational levels while constructing a building (KHALIL; KAMARUZZAMAN; BAHARUM, 2016). BPE aims to improve the quality of project management and construction by providing a more sustainable construction (IBEM et al., 2013); providing basic information on users' needs, preferences and satisfaction (VISCHER, 2008) and providing feedback on the causes and effects of environmental issues related to buildings, thus assisting long-term planning and management of a building life cycle (MEIR et al., 2009).

According to Nazeer and De Silva (2016), the performance approach analyses several dimensions of performance within the same building. These dimensions relate to the functional, design, technical, economic, environmental and social aspects of construction.

Post-occupancy Evaluation (POE) is one of the most used instruments for gathering information and for feedback of the systematic process (BPE). According to Finch (2012), this evaluation consists of checking if the conditions of the environment in use are satisfactory regarding the performance of the built environment, considering the users' point of view. POE in innovative construction systems can be an instrument to improve the system itself or specific maintenance procedures during its use (VILLA; ORNSTEIN, 2013).

\section{Research method}

Constructive research or design science research is the research strategy adopted for the development of this study. According to Dresch, Lacerda and Júnior (2015), design science research is a method used during research to obtain an artifact or a prescription. It is intended to solve specific problems, not necessarily seeking an ideal solution, but a satisfactory solution for each situation, which may even serve as a goal of use and knowledge for the academy. It can further support the development and construction of an artifact and contribute to strengthen existing knowledge bases. An artifact can be classified as a construct, model, method and instantiation. In this study, the developed artifact will be the method to evaluate LWF buildings focusing on social housing. A method can be considered as a set of steps to gain certain knowledge about a subject. In this case, this study seeks knowledge of the criteria that must be evaluated during a BPE of a light wood frame construction. The systematic method developed to evaluate buildings in LWF comprises four main steps that can be seen in Figure 1.

\section{Identifying performance criteria}

In order to develop the evaluation method, the first step was to create a framework of the criteria, as well as their respective sub-criteria, which should be managed to carry out such an action. Thus, this first step consisted of identifying all possible items to be evaluated in a performance evaluation. For this activity, four research sources were consulted:

(a) performance standards;

(b) sustainability performance certifications for buildings;

(c) standards/guidelines related to wood and/or LWF constructions; and

(d) a systematic literature review that searched for studies which established methods to evaluate the performance of buildings based on pre-established criteria. 
Figure 1 - LWF performance evaluation method in Brazil

\begin{tabular}{|c|c|c|c|}
\hline $\begin{array}{l}\text { 1) Identify performance } \\
\text { criteria }\end{array}$ & $\begin{array}{l}\text { 2) Validate specific criteria } \\
\text { for LWF }\end{array}$ & $\begin{array}{l}\text { 3) Validation of sub- } \\
\text { criteria } \\
\end{array}$ & $\begin{array}{l}\text { 4) Weight } \\
\text { generation }\end{array}$ \\
\hline $\begin{array}{l}\text { Literature search } \\
+ \\
\text { Performance standards } \\
+ \\
\text { Environmental } \\
\text { performance } \\
\text { certifications } \\
+ \\
\text { LWF standards }\end{array}$ & $\begin{array}{l}\text { IV SIMPÓSIO MADEIRA } \\
\text { \& CONSTRUÇÃO } \\
\text { (Questionnaire) } \\
+ \\
\text { Factor analysis }\end{array}$ & $\begin{array}{l}\text { Delphi with LWF } \\
\text { experts } \\
+ \\
\text { Factor analysis }\end{array}$ & $\begin{array}{l}\text { Meeting } \\
+ \\
\text { Creation of the } \\
\text { scale }\end{array}$ \\
\hline $\begin{array}{l}\text { Results } \\
22 \text { criteria } \\
79 \text { sub-criteria }\end{array}$ & $\begin{array}{l}\text { Results } \\
21 \text { criteria validated } \\
\text { Organised into } 6 \\
\text { dimensions }\end{array}$ & \begin{tabular}{|l}
$\begin{array}{l}\text { Results } \\
41 \text { sub-criteria } \\
\text { validated }\end{array}$ \\
19 criteria validated \\
Organised into 5 \\
dimensions
\end{tabular} & $\begin{array}{l}\text { Results } \\
\text { Weight scale }\end{array}$ \\
\hline
\end{tabular}

The BPE method can be understood as the systematic structure to select the criteria to be measured and the application of the method in buildings.

\section{Validate specific criteria for LWF}

The second stage of the research aimed to validate the criteria found in the first step, identifying which of them were actually applicable in a performance evaluation of light wood frame buildings. In addition to the literature, questionnaires were distributed to representatives from the LWF segment in Brazil, and a total of 43 questionnaires were answered. In this questionnaire, the respondents used the Likert scale (1-5), which measures the level of importance, where 1 is considered the most important factor and 5 is the least important factor, generating weights for each one of the criteria presented in the study.

In order to validate the questionnaire used in the study, its reliability was tested using the Cronbach alpha coefficient, which is the average of all the half-to-half coefficients that result from the different ways of dividing the scale items in half. The coefficient expression is given by Equation 1:

$\propto=\frac{N \bar{\rho}}{[1+\bar{\rho}(N-1)}$

Eq. 1

Where:

$\mathrm{N}$ - number of items; and

$\bar{\rho}$ - average of the linear correlation coefficients between the items.

In addition, in this study, the software Minitab was used to calculate the Cronbach alpha coefficient.

With these data, exploratory factorial analysis was used to determine the variables' behaviour, in the case of the criteria. A factor analysis is a set of multivariate techniques to group related variables into factors that represent them (PESTANA; GAGEIRO, 2005). The variables were grouped into factors considering the factorial loads (result of the factorial analysis). It is important to emphasize that this statistical analysis reveals the views of the respondents of this research.

The assumptions of the factorial analysis are distribution normalities, the Kaiser-Meyer-Olkin test and the Bartlett sphericity test. In relation to normality, the sample can be considered normal by the central limit theorem (n > 30) (TRIOLA, 1999). 
The Kaiser-Meyer-Olkin (KMO) test is calculated by the matrix Measure of Sampling Adequacy (MSAEquation 2) that evaluates the adequacy of the factorial analysis:

$M S A=\frac{\sum \sum_{j \neq k} r_{j k}^{2}}{\sum \sum_{j \neq k} r_{j k}^{2}+\sum \sum_{j \neq k} q_{j k}^{2}}$

Where:

$r_{j k}^{2}$ - is the square of the elements of the original correlation matrix (off-diagonal), that is, $\mathrm{r}_{\mathrm{jk}}$ represents the simple linear correlation coefficient between the variables $\mathrm{Xj}$ and $\mathrm{Xk}$; and

$q_{j k}^{2}$ - is the square of the off-diagonal elements of the Anti-image correlation matrix, where $\mathrm{q}_{\mathrm{jk}}$ represents the partial linear correlation coefficient between the variables $\mathrm{Xj}$ and $\mathrm{Xk}$.

High MSA values (between 0.5 and 1.0) indicate that the factorial analysis is appropriate, while low values below 0.5 indicate that the factorial analysis may be inadequate. Khair et al. (2015) recommended using values above 0.5 in their performance analysis research.

The Bartlett sphericity test verifies the hypothesis that the variables are not correlated in the population. The basic hypothesis states that the population correlation matrix is an identity matrix which indicates that the factorial model is inappropriate. The test statistic is given by Equation 3:

$\chi^{2}=-\left[(n-1)-\frac{2 p+5}{6}\right] \ln |R|$

Eq. 3

Where:

$\mathrm{n}$ - sample size;

$\mathrm{p}$ - number of variables; and

$|R|$ - determinant of the correlation matrix.

Having a chi-square distribution with degrees of freedom, by Equation 4:

$v=\frac{p(p-1)}{2}$

Statistica software was used for both tests. In total, six factors, or dimensions, were regrouped according to the Varimax rotation base, which aims to optimise factor organisation. Then, the next step was to observe factorial loads and commonalities, which is the total variance of the variable explained by common factors. The value of factor loads can also be a determinant for the validation of the criterion. In this study, criteria that presented a factorial load above 0.3 were considered as validated, such as the study by Candido et al. (2016), who made a factorial analysis for the selection criteria.

\section{Validation of sub-criteria}

In the third step, the Delphi technique was used with six experts representing LWF in Brazil. These are engineers who work in the market or within the academy with innovative construction systems. At this step, the objective was to have the experts select and agree on the sub-criteria needed to evaluate a popular building made of LWF.

The Delphi technique is an instrument used to help decision making collectively. Through a systematic process, it generates consensus among experts in a fast and organised way and can, according to Coelho (2003), be carried out online when there is no possibility of a face-to-face meeting. For the operationalisation of the activity, specialists from the study area need to be selected. Linstone and Turoff (2002) emphasise the need to form a good group of respondents, who can provide honest responses in a responsible and committed way.

The technique was used as follows: the experts received the sub-criteria online and should select those considered relevant to the performance evaluation of buildings using LWF, according to their view. Later, the responses were collected, and the data were accounted for. The sub-criteria that have already obtained consensus were removed from the study and separated. The rest was kept and re-sent. This activity took place during four rounds until there was consensus among the specialists. During this activity, the specialists were able to check each other's answers without being identified. In addition, the specialists had the opportunity of receiving information from the literature on some specific issues in case of doubts. They also had the opportunity to make suggestions and comments on the study in development. The rounds took place from October to December 2017. 


\section{Weight generation}

Since each sub-criterion had a different degree of importance for the performance evaluation, the importance of each one can be measured by attributing weights, which show the importance of each sub-criterion in relation to the others. Thus, the fourth step was to generate weights for each of the sub-criteria. For this activity, the group of agents responsible for the LWF standard in Brazil, consisting of 23 professionals, was consulted and the weights were obtained from the opinion of each specialist. Adopting the Likert scale, each agent can score the sub-criterion with values between 1 and 5, where 1 is considered the most important factor and 5 is the least important factor.

In order to validate the reliability of this questionnaire again the calculation of Cronbach's alpha coefficient was performed. Following weight attribution, both the criteria and the sub-criteria, the structures of Nazeer and De Silva (2016), which also refer to Hong (2008), were followed.

Having established the weights, a scale was made according to the weighted average performed, that is, the most important sub-criteria with the highest average is first on the scale and the least important is forty-first on the scale, considering that there are 41 sub-criteria, where wj is the weight assigned to attribute $\mathrm{j}$, and (Equation 5):

$\sum w j=1$

Eq. 5

This scale was based on Hong (2008). The weighted average was calculated using the following equation (Equation 6):

$M=\frac{\sum\left(V_{i} x F_{i}\right)}{n}$

Eq. 6

Where:

M - weighted average;

$\mathrm{Vi}$ - the value given by the respondent to each sub-criterion; and

$\mathrm{Fi}$ - the frequency of responses and $\mathrm{n}$ is the total number of respondentes.

In the case where there is a tie between the sub-criteria in the ranking, the average of its classification will be used. For example, if two attributes are disputing the second and third place, the number 2.5 will be assigned to both.

The weight of each sub-criterion was obtained from the following Equation 7, based on Nazeer and De Silva (2016):

$w_{j}=\frac{\frac{1}{r_{j}}}{\sum_{k=1}^{n} \frac{1}{r_{k}}}$

Where:

wj - the weight of each sub-criterion, $(i=1,2,3, \ldots, 41)$;

$\mathrm{rj}$ - the position in the established ranking of each sub-criterion; and

rk - sum of rj.

The purpose of this procedure is to arrive at a number of points distributed by the sub-criterion, according to their importance. For this purpose, from the calculation of wj, according to Hong (2008) and Nazeer and De Silva (2016), a constant is calculated so that the criterion with lower wj receives 1 point. Knowing that the last sub-criterion received the value of $\mathrm{w}_{-} 41=0.005672$, following the logic described, a constant of 173 was found. Thus, 173 points represent the total number of points to be distributed in the performance evaluation of the building, and each criterion has its maximum number of available points according to the importance given in the previous steps of the study.

From this total, a weight can be established for each sub-criterion, thus creating a weight score (sj), which can be calculated by the equation (Equation8):

$s_{j}=173 x w_{j}$

Eq. 8

Having this score, the literature was once again consulted to verify how the standard measurement thresholds of the environmental certifications were established to elaborate a specific one for this method. Thus, through this scale a diagnosis for each criterion and sub-criterion could be made.

558 Sotsek, N. C.; Leitner, D. S.; Santos, B. L.; Messias, J. dos S. N.; Santos, A. de P. L. 
Figure 2 - Evaluation method for building performance in LWF in Brazil

\begin{tabular}{|c|c|c|c|c|}
\hline Dimension 1 & Dimension 2 & Dimension 3 & Dimension 4 & Dimension 5 \\
\hline $\begin{array}{l}\text { 1.1 Protection and } \\
\text { Security } \\
\text { 1.2Electrical } \\
\text { installations } \\
\text { 1.3 Hydraulic facilities } \\
\text { 1.4Telecommunication } \\
\text { facilities } \\
\text { 1.5 Organisation of the } \\
\text { environment }\end{array}$ & $\begin{array}{l}\text { 2.1 Thermal } \\
\text { comfort } \\
2.2 \text { Acoustic } \\
\text { comfort } \\
\text { 2.3 Visual comfort } \\
\text { 2.4 Internal air } \\
\text { quality }\end{array}$ & $\begin{array}{l}\text { 3.1 } \\
\text { Buildingdocumentation } \\
3.2 \text { Training of } \\
\text { residents } \\
\text { 3.3Facility } \\
\text { managementby } \\
\text { residents }\end{array}$ & $\begin{array}{l}\text { 4.1 Structural } \\
\text { durability } \\
4.2 \text { Maintenance } \\
4.3 \text { Sealings }\end{array}$ & $\begin{array}{l}\text { 5.1Satisfaction of } \\
\text { residents } \\
\text { 5.2 Energy } \\
\text { efficiency } \\
\text { 5.3 Costs } \\
5.4 \text { Physical } \\
\text { appearance }\end{array}$ \\
\hline $\begin{array}{l}\text { 1.1.1 Fire safety } \\
\text { 1.1.2 Protection against } \\
\text { harmful micro- } \\
\text { organisms, insects and } \\
\text { animals } \\
\text { 1.1.3 Structural strength } \\
\text { safety (walls) } \\
\text { 1.2.1 Ease of access for } \\
\text { electrical components } \\
\text { 1.2.2 Cleaning and } \\
\text { safety components of } \\
\text { electrical installations } \\
\text { 1.3.1 Ease of access to } \\
\text { hydraulic mechanisms } \\
\text { 1.3.2 Cleaning and } \\
\text { security of internal and } \\
\text { external hydraulic } \\
\text { facilities } \\
\text { 1.4.1 Ease of access to } \\
\text { telecommunication } \\
\text { mechanisms } \\
\text { 1.5.1 Plan of preventive } \\
\text { and continuous } \\
\text { maintenance in all the } \\
\text { installations } \\
\text { 1.5.2 Flexibility and } \\
\text { adaptability }\end{array}$ & $\begin{array}{l}\text { 2.1.1 Internal } \\
\text { ambient temperature } \\
2.1 .2 \text { Thermal } \\
\text { variation (4 } \\
\text { seasons/winter- } \\
\text { summer) } \\
\text { 2.2.1 Internal noise } \\
\text { level } \\
\text { 2.2.2 Level of } \\
\text { external noise } \\
\text { (neighbours, } \\
\text { neighbourhood, } \\
\text { street among others) } \\
\text { 2.3.1 Natural } \\
\text { lighting } \\
\text { 2.4.1 Circulation of } \\
\text { air } \\
\text { 2.4.2 Air humidity }\end{array}$ & $\begin{array}{l}\text { 3.1.1 Electrical, } \\
\text { hydraulic, } \\
\text { telecommunications, } \\
\text { structural, thermal (if } \\
\text { any) } \\
\text { 3.1.2 Environmental } \\
\text { plan (sustainability) } \\
\text { 3.1.3 Maintenance plan } \\
\text { 3.2.1 Residents' Guide } \\
\text { 3.3.1 Ongoing } \\
\text { maintenance by } \\
\text { residents } \\
\text { 3.3.2 Awareness } \\
\text { program } \\
\text { 3.3.3 Relation builder } \\
\text { vs residents }\end{array}$ & $\begin{array}{l}\text { 4.1.1 Internal } \\
\text { surfaces of the } \\
\text { enterprise (Cracks, } \\
\text { fissures, holes, } \\
\text { etc.) } \\
4.1 .2 \text { External } \\
\text { surfaces of the } \\
\text { enterprise (Cracks, } \\
\text { fissures, holes, } \\
\text { etc.) } \\
4.2 .1 \text { Preventive of } \\
\text { the internal } \\
\text { surfaces of the } \\
\text { enterprise } \\
4.2 .2 \text { Preventive of } \\
\text { the external } \\
\text { surfaces of the } \\
\text { project } \\
4.3 .1 \text { Insulation } \\
\text { (protection of air } \\
\text { intake) } \\
4.3 .2 \text { Water } \\
\text { tightness }\end{array}$ & $\begin{array}{l}\text { 5.1.1 Security of } \\
\text { life and real estate } \\
5.1 .2 \text { Feeling of } \\
\text { "belonging to the } \\
\text { environment" } \\
\text { 5.1.3 Feeling of } \\
\text { "well-being"" } \\
\text { 5.1.4 Productivity } \\
\text { and Performance } \\
\text { 5.2.1 Rainwater } \\
\text { harvesting } \\
\text { management } \\
\text { 5.2.2 Renewable } \\
\text { energy } \\
\text { management } \\
\text { (solar capture) } \\
\text { 5.2.3 } \\
\text { Management of } \\
\text { polluting gases } \\
5.3 .1 \text { Maintenance } \\
\text { costs } \\
\text { 5.3.2 Expected } \\
\text { cost X actual } \\
\text { (water, electricity, } \\
\text { gas, etc.) } \\
5.4 .1 \text { Quality of } \\
\text { materials used in } \\
\text { building } \\
5.4 .2 \text { Maintaining } \\
\text { the physical } \\
\text { appearance of the } \\
\text { building }\end{array}$ \\
\hline
\end{tabular}

\section{Results and discussion}

As a result, 5 dimensions, 19 criteria and 41 sub-criteria were validated, which were established according to the following four steps. The method can be seen in Figure 2.

\section{Weight generation}

Using the four research sources, 22 criteria and 41 sub-criteria were identified in the literature (Table 1). These criteria and sub-criteria were identified in:

(a) two systematic literature reviews (SLR), one made with studies related specifically to post-occupancy evaluation (POE) and another with building performance evaluation (BPE);

(b) performance standards: NBR 15575 (ABNT, 2013), ISO 6241 (INTERNATIONAL..., 1984), ISO 19208 (INTERNATIONAL ..., 2016), ISO 15928 (INTERNATIONAL ..., 2015), CTE (MINISTERIO DE VIVENCIA, 2006), DBH (DEPARTMENT..., 2010), ASMT (AMERICAN..., 2017), BAPF (QUEENSLAND..., 2008) and NBC (BUREAU..., 2016); 
(c) environmental Certifications regarding building performance criteria: Building Research Establishment Environmental Assessment Method (BREEAM), Leadership in Energy and Environmental Design (LEED), VERDE, Comprehensive Assessment System for Built Environment Efficiency (CASBEE), Green Start, International Initiative for a Sustainable Built Environment (iiSBE), Green Mark, National Australian Built Environment Rating System (NABERS), Green Globes, International Well Building Institute (Well), and the Brazilian "Selo Azul" (Blue Seal) and "Aquas"; and

(d) finally, documents that guide the construction system in Brazil: SINAT No 005 and DATec No 020-C (MINISTÉRIO DAS CIDADES, 2017a, 2017b), which have been developed based on other international documents.

Table 1 - The criteria and sub-criteria identified in the literature(Continues...)

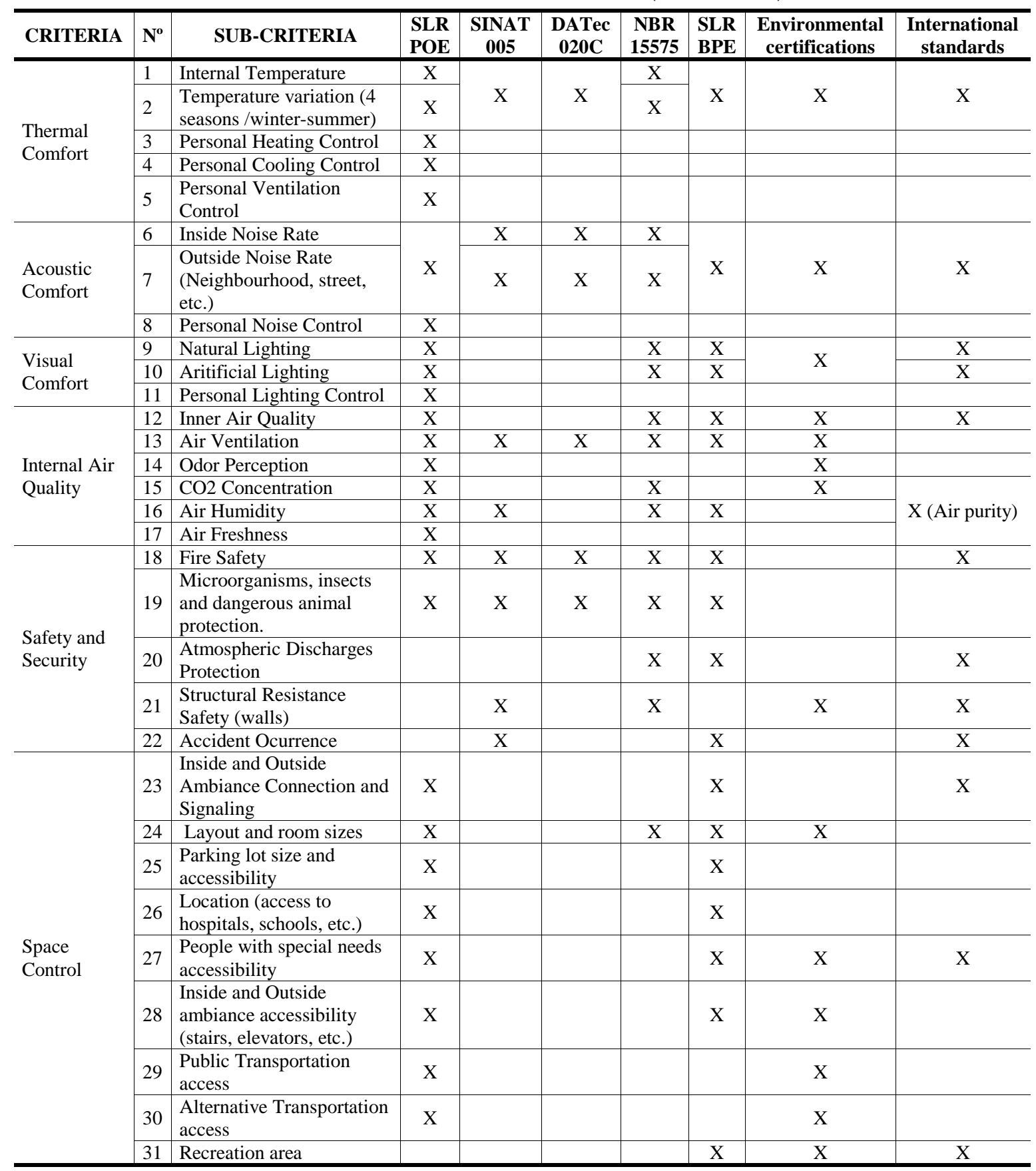

560 Sotsek, N. C.; Leitner, D. S.; Santos, B. L.; Messias, J. dos S. N.; Santos, A. de P. L. 
Table 1 - The criteria and sub-criteria identified in the literature (continued)

\begin{tabular}{|c|c|c|c|c|c|c|c|c|c|}
\hline CRITERIA & $\mathbf{N}^{\mathbf{0}}$ & SUB-CRITERIA & $\begin{array}{l}\text { SLR } \\
\text { POE }\end{array}$ & $\begin{array}{c}\text { SINAT } \\
005\end{array}$ & \begin{tabular}{|c|} 
DATec \\
020C \\
\end{tabular} & \begin{tabular}{|l|} 
NBR \\
15575 \\
\end{tabular} & \begin{tabular}{|l|} 
SLR \\
BPE
\end{tabular} & \begin{tabular}{|c|} 
Environmental \\
certifications
\end{tabular} & \begin{tabular}{|c|}
$\begin{array}{c}\text { International } \\
\text { standards }\end{array}$ \\
\end{tabular} \\
\hline \multirow{8}{*}{$\begin{array}{l}\text { Resident's } \\
\text { satisfaction }\end{array}$} & 32 & Health conditions & $\bar{X}$ & & & $\mathrm{X}$ & $\bar{X}$ & & $\bar{X}$ \\
\hline & 33 & Privacy of the residents & $\mathrm{X}$ & & & & $\mathrm{X}$ & & \\
\hline & 34 & Feeling of "belonging" & & & & & $\mathrm{X}$ & & \\
\hline & 35 & Feeling of "well-being" & $\mathrm{X}$ & & & & $\mathrm{X}$ & & $\mathrm{X}$ \\
\hline & 36 & External View & $\mathrm{X}$ & & & & & $\mathrm{X}$ & \\
\hline & 37 & $\begin{array}{l}\text { Residents' engagement } \\
\text { with the community } \\
\text { (neighbourhood) }\end{array}$ & & & & & $\mathrm{X}$ & $\mathrm{X}$ & $\mathrm{X}$ \\
\hline & 38 & $\begin{array}{l}\text { Performance and } \\
\text { productivity }\end{array}$ & $\mathrm{X}$ & & & & $\mathrm{X}$ & & \\
\hline & 39 & $\begin{array}{l}\text { Life and property } \\
\text { safety }\end{array}$ & $\mathrm{X}$ & & & $\mathrm{X}$ & $\mathrm{X}$ & & $\mathrm{X}$ \\
\hline \multirow{2}{*}{$\begin{array}{l}\text { Structural } \\
\text { Durability }\end{array}$} & 40 & $\begin{array}{l}\text { Internal surfaces } \\
\text { (cracks, fissures, holes, } \\
\text { etc.) }\end{array}$ & & \multirow[b]{2}{*}{$X$} & \multirow{2}{*}{$X$} & \multirow{2}{*}{$X$} & $\mathrm{X}$ & & \\
\hline & 41 & $\begin{array}{l}\text { External surfaces } \\
\text { (cracks, fissures, holes, } \\
\text { etc.) }\end{array}$ & & & & & $\mathrm{X}$ & & \\
\hline \multirow{2}{*}{ Maintance } & 42 & $\begin{array}{l}\text { Preventive of the } \\
\text { internal superficies }\end{array}$ & & \multirow{2}{*}{$\mathrm{X}$} & \multirow{2}{*}{$\mathrm{X}$} & \multirow{2}{*}{$\mathrm{X}$} & $\mathrm{X}$ & \multirow{2}{*}{$\mathrm{X}$} & \\
\hline & 43 & $\begin{array}{l}\text { Preventive of the } \\
\text { external superficies }\end{array}$ & & & & & $\mathrm{X}$ & & \\
\hline \multirow{3}{*}{$\begin{array}{l}\text { Electrical } \\
\text { Installations }\end{array}$} & 44 & $\begin{array}{l}\text { Energy consumption } \\
\text { and supply }\end{array}$ & $\mathrm{X}$ & & & $\mathrm{X}$ & $\mathrm{X}$ & & $\mathrm{X}$ \\
\hline & 45 & $\begin{array}{l}\text { Good accessibility to } \\
\text { electrical components } \\
\text { (plugs and connectors) }\end{array}$ & & $\mathrm{X}$ & $\mathrm{X}$ & $\mathrm{X}$ & & & \\
\hline & 46 & $\begin{array}{l}\text { Cleaning and safety of } \\
\text { the electrical } \\
\text { installation components } \\
\text { (plugs and connectors) }\end{array}$ & & & & $\mathrm{X}$ & $\mathrm{X}$ & & \\
\hline \multirow{4}{*}{$\begin{array}{l}\text { Hydraulic } \\
\text { Installations }\end{array}$} & 47 & $\begin{array}{l}\text { Consumption and } \\
\text { water supply }\end{array}$ & $\mathrm{X}$ & & & $\mathrm{X}$ & $\mathrm{X}$ & & $\mathrm{X}$ \\
\hline & 48 & $\begin{array}{l}\text { Easy access to } \\
\text { hydraulic mechanisms }\end{array}$ & & $\mathrm{X}$ & $\mathrm{X}$ & $\mathrm{X}$ & & & \\
\hline & 49 & Water quality & & & & $\mathrm{X}$ & $\mathrm{X}$ & & \\
\hline & 50 & $\begin{array}{l}\text { Cleaning and security } \\
\text { of internal and external } \\
\text { hydraulic facilities }\end{array}$ & & & & $\mathrm{X}$ & $\mathrm{X}$ & & \\
\hline $\begin{array}{l}\text { Telecommu- } \\
\text { nication } \\
\text { Installations }\end{array}$ & 51 & $\begin{array}{l}\text { Easy access to } \\
\text { telecommunication } \\
\text { mechanisms } \\
\text { (telephone, internet, } \\
\text { etc.) }\end{array}$ & & & & & & $\mathrm{X}$ & $\mathrm{X}$ \\
\hline \multirow{3}{*}{$\begin{array}{l}\text { Environmen- } \\
\text { tal } \\
\text { Organisation }\end{array}$} & 52 & $\begin{array}{l}\text { Cleaning of internal } \\
\text { and external spaces }\end{array}$ & $\mathrm{X}$ & $\mathrm{X}$ & & $\mathrm{X}$ & $\mathrm{X}$ & & \\
\hline & 53 & $\begin{array}{l}\text { Plan of preventive and } \\
\text { continuous } \\
\text { maintenance in all the } \\
\text { installations (electrical, } \\
\text { hydraulic, thermal - if } \\
\text { there are any, etc.) }\end{array}$ & & $\mathrm{X}$ & $\mathrm{X}$ & $X$ & $X$ & & \\
\hline & 54 & $\begin{array}{l}\text { Flexibility and } \\
\text { Adaptability }\end{array}$ & & & & & $X$ & $X$ & $X$ \\
\hline \multirow[t]{2}{*}{ Sealings } & 55 & $\begin{array}{l}\text { Isolation (protection } \\
\text { against air intake) }\end{array}$ & & & & $X$ & $X$ & & $\mathrm{X}$ \\
\hline & 56 & Watertightness & & $X$ & $X$ & $\mathrm{X}$ & $X$ & & \\
\hline
\end{tabular}


Table 1 - The criteria and sub-criteria identified in the literature (continued)

\begin{tabular}{|c|c|c|c|c|c|c|c|c|c|}
\hline CRITERIA & $\mathbf{N}^{\mathbf{0}}$ & SUB-CRITERIA & $\begin{array}{l}\text { SLR } \\
\text { POE }\end{array}$ & \begin{tabular}{|c|}
$\begin{array}{c}\text { SINAT } \\
005\end{array}$ \\
\end{tabular} & \begin{tabular}{|c|} 
DATec \\
020C \\
\end{tabular} & $\begin{array}{l}\text { NBR } \\
15575 \\
\end{array}$ & $\begin{array}{l}\text { SLR } \\
\text { BPE }\end{array}$ & \begin{tabular}{|c|} 
Environmental \\
certifications
\end{tabular} & \begin{tabular}{|c|}
$\begin{array}{c}\text { International } \\
\text { standards }\end{array}$ \\
\end{tabular} \\
\hline \multirow{2}{*}{$\begin{array}{l}\text { Waste } \\
\text { Management }\end{array}$} & 57 & $\begin{array}{l}\text { Collection and waste } \\
\text { facilities }\end{array}$ & $\mathrm{X}$ & & & & $\mathrm{X}$ & & \multirow{2}{*}{$X$} \\
\hline & 58 & $\begin{array}{l}\text { Separation of recycled } \\
\text { and organic waste }\end{array}$ & & & & & $\mathrm{X}$ & $\mathrm{X}$ & \\
\hline \multirow{5}{*}{$\begin{array}{l}\text { Energy } \\
\text { Efficiency }\end{array}$} & 59 & $\begin{array}{l}\text { Rainwater harvesting } \\
\text { management }\end{array}$ & & & & & $\mathrm{X}$ & & \multirow{5}{*}{$\begin{array}{l}\text { Energy } \\
\text { Efficiency }\end{array}$} \\
\hline & 60 & $\begin{array}{l}\text { Renewable energy } \\
\text { management (solar } \\
\text { capture) }\end{array}$ & & & & & & $X$ & \\
\hline & 61 & $\begin{array}{l}\text { Control and search for } \\
\text { waste reduction }\end{array}$ & & & & & $\mathrm{X}$ & $X$ & \\
\hline & 62 & $\begin{array}{l}\text { Proper treatment of } \\
\text { sewage }\end{array}$ & & & & & $\mathrm{X}$ & & \\
\hline & 63 & $\begin{array}{l}\text { Management of } \\
\text { polluting gases }\end{array}$ & & & & & $\mathrm{X}$ & $\mathrm{X}$ & \\
\hline \multirow{3}{*}{ Expenses } & 64 & Investments & $\mathrm{X}$ & & & & & & $\mathrm{X}$ \\
\hline & 65 & $\begin{array}{l}\text { Maintenance costs } \\
\text { (materials, equipment, } \\
\text { people) }\end{array}$ & $\mathrm{X}$ & & & $\mathrm{X}$ & $\mathrm{X}$ & $X$ & $\mathrm{X}$ \\
\hline & 66 & $\begin{array}{l}\text { Expected cost VS. } \\
\text { actual (water, } \\
\text { electricity, gas, etc.) }\end{array}$ & & & & & $\mathrm{X}$ & $X$ & \\
\hline \multirow{4}{*}{$\begin{array}{l}\text { Physical } \\
\text { Appearance }\end{array}$} & 67 & $\begin{array}{l}\text { Aesthetics of the } \\
\text { building }\end{array}$ & $\mathrm{X}$ & & & & $\mathrm{X}$ & $X$ & \\
\hline & 68 & $\begin{array}{l}\text { Physical appearance of } \\
\text { the actual building } \\
\text { VS.project appearance }\end{array}$ & & & & & $\mathrm{X}$ & $X$ & \\
\hline & 69 & $\begin{array}{l}\text { Quality of the materials } \\
\text { used in the building }\end{array}$ & $\mathrm{X}$ & $\mathrm{X}$ & $\mathrm{X}$ & $\mathrm{X}$ & $\mathrm{X}$ & & \\
\hline & 70 & $\begin{array}{l}\text { Maintaining the } \\
\text { physical appearance of } \\
\text { the building }\end{array}$ & & \multirow[b]{2}{*}{$\mathrm{X}$} & \multirow[b]{2}{*}{$\mathrm{X}$} & $\mathrm{X}$ & & \multirow[b]{2}{*}{$X$} & \\
\hline Landscaping & 71 & $\begin{array}{l}\text { Plan of preventive and } \\
\text { continuous } \\
\text { maintenance of the } \\
\text { landscaping }\end{array}$ & & & & & $\mathrm{X}$ & & \\
\hline \multirow{4}{*}{$\begin{array}{l}\text { Building } \\
\text { Documen- } \\
\text { tation }\end{array}$} & 72 & $\begin{array}{l}\text { Electrical, hydraulic, } \\
\text { mechanical and } \\
\text { thermal projects }\end{array}$ & & $\mathrm{X}$ & $\mathrm{X}$ & $\mathrm{X}$ & & & \\
\hline & 73 & Security Plan & & & & & $X$ & $\mathrm{X}$ & \\
\hline & 74 & $\begin{array}{l}\text { Environmental plan } \\
\text { (sustainability) }\end{array}$ & & & & $\mathrm{X}$ & $\mathrm{X}$ & & $\mathrm{X}$ \\
\hline & 75 & Maintenance plan & & $\mathrm{X}$ & $\mathrm{X}$ & $\mathrm{X}$ & $\mathrm{X}$ & $\mathrm{X}$ & \\
\hline $\begin{array}{l}\text { Residence } \\
\text { Drill }\end{array}$ & 76 & Guide to residents & & $\mathrm{X}$ & $\mathrm{X}$ & $X$ & $\mathrm{X}$ & $X$ & \\
\hline \multirow{3}{*}{$\begin{array}{l}\text { Facility } \\
\text { management } \\
\text { by the } \\
\text { residents }\end{array}$} & 77 & $\begin{array}{l}\text { Continuous } \\
\text { maintenance made by } \\
\text { residents }(3,6,9,12 \\
\text { months) }\end{array}$ & & $\mathrm{X}$ & $X$ & $\mathrm{X}$ & $\mathrm{X}$ & & \\
\hline & 78 & Awareness Programs & & & & & $\mathrm{X}$ & & \multirow[b]{2}{*}{$\mathrm{X}$} \\
\hline & 79 & $\begin{array}{l}\text { Relation construction } \\
\text { company VS. } \\
\text { Residents }\end{array}$ & & & & & $X$ & & \\
\hline
\end{tabular}

When analysing these documents, it was observed that there is no standard for organising the criteria and sub-criteria. Thus, the authors made their own structure, trying to organise them into groups related to each other. 


\section{Validate specific criteria for LWF}

In order to verify which of these identified criteria should be used for the analysis of an LWF building in Brazil, a questionnaire was made and distributed at the IV Wood \& Construction Symposium that took place on September 20 and 21, 2017 at the Federal University of Paraná. After distributing the questionnaire, 43 answers were obtained.

The respondents gave their opinions answering the following question: To evaluate a light weight frame building performance, which criteria are important and should be considered for analysis? Assign weights to each of the criteria. Use the Likert scale, assigning 0 for the criterion that does not apply, 1 for the minor criterion, 2 for the least important, 3 for important, 4 more important and 5 very important.

Regarding reliability, in this research the identified result was in the range of 0.8837 , according to Cronbach's alpha test. According to Pallant (2011), alpha values higher than 0.7 are considered sufficient, which confers satisfactory reliability to the questionnaire.

Using the 43 responses, the weighted average and variance of each of the 22 criteria was calculated, as can be seen in Table 2. Criteria with an average above 3 were validated at this step of the study. The average value 3 was considered as the stipulated threshold following the determination of other studies in the literature similar to this research (HONG, 2008; ELYNA MYEDA; NIZAM KAMARUZZAMAN; PITT, 2011). Therefore, the criterion "Landscaping" was excluded, so that 21 criteria were validated.

Table 2 - Criteria evaluated throughout the questionnaire

\begin{tabular}{|c|c|c|c|c|c|c|c|c|}
\hline \multirow{2}{*}{ Criteria } & \multicolumn{6}{|c|}{ Recurrence } & \multirow{2}{*}{ Average } & \multirow{2}{*}{$\begin{array}{l}\text { Standard } \\
\text { Deviation }\end{array}$} \\
\hline & $\mathbf{0}$ & 1 & 2 & 3 & 4 & 5 & & \\
\hline Thermal comfort & 0 & 0 & 0 & 11 & 2 & 30 & 4,4 & 0,9 \\
\hline Acoustic comfort & 0 & 1 & 0 & 11 & 7 & 24 & 4,2 & 1 \\
\hline Visual comfort & 0 & 1 & 2 & 21 & 9 & 9 & 3,6 & 1 \\
\hline Internal air quality & 0 & 0 & 2 & 17 & 6 & 18 & 3,9 & 1 \\
\hline Protection and security & 0 & 2 & 1 & 12 & 4 & 22 & 3,9 & 1,3 \\
\hline Space control & 0 & 5 & 5 & 17 & 5 & 7 & 3,1 & 1,2 \\
\hline Satisfaction of residents & 0 & 3 & 0 & 11 & 8 & 21 & 4 & 1,2 \\
\hline Structural Durability & 0 & 1 & 0 & 7 & 3 & 32 & 4,5 & 0,9 \\
\hline Maintenance & 0 & 0 & 1 & 12 & 10 & 20 & 4,1 & 0,9 \\
\hline Electrical installations & 0 & 2 & 5 & 15 & 9 & 12 & 3,6 & 1,2 \\
\hline Hydraulic facilities & 0 & 0 & 6 & 16 & 8 & 13 & 3,7 & 1,1 \\
\hline Telecommunication facilities & 0 & 6 & 7 & 17 & 3 & 9 & 3,1 & 1,3 \\
\hline Organisation of the environment & 0 & 4 & 7 & 16 & 2 & 12 & 3,3 & 1,3 \\
\hline Sealings & 0 & 1 & 3 & 8 & 4 & 27 & 4,2 & 1,1 \\
\hline Waste Management & 0 & 2 & 3 & 18 & 6 & 14 & 3,6 & 1,2 \\
\hline Energy Efficiency & 0 & 0 & 3 & 9 & 7 & 23 & 4,2 & 1 \\
\hline Costs & 0 & 0 & 5 & 7 & 7 & 24 & 4,1 & 1,2 \\
\hline Physical appearance & 0 & 5 & 8 & 12 & 8 & 10 & 3,2 & 1,3 \\
\hline Landscaping & 0 & 13 & 10 & 8 & 3 & 7 & 2,4 & 1,5 \\
\hline Building documentation & 0 & 5 & 2 & 16 & 6 & 11 & 3,4 & 1,3 \\
\hline Training of residents & 0 & 3 & 5 & 11 & 11 & 12 & 3,6 & 1,2 \\
\hline Facility management by residents & 0 & 4 & 3 & 15 & 10 & 11 & 3,5 & 1,2 \\
\hline
\end{tabular}

Note: the criteria with the highest scores were: structural durability (4.55), thermal comfort (4.44), sealing and acoustic comfort, which tied (4.23). The least important criteria considered by the respondents were: landscaping (2.42), telecommunication facilities (3.05) and space control (3.08). In addition, the KMO obtained in this research was 0.6243 , which confers its adequacy. The Bartlett test presented a significance level of 0.000 , showing that there is a correlation between the criteria. Then, in Table 3, the result of the factorial analysis, together with the six factors, or dimensions, established for grouping the criteria, the respective factorial loads, the values of variance and commonality can be seen. In this research, all loads above 0.3 were considered valid, according to research by Candido et al. (2016), who did a factorial analysis for the criteria selection. 
Table 3 - Factor analysis results for the 21 validated criteria

\begin{tabular}{|c|c|c|c|c|c|}
\hline Criteria & Dimension & Factorial weight & Eigenvalues & Variance & Cumulated \\
\hline & Dimension 1 & & \multirow{6}{*}{6.55301} & \multirow{6}{*}{4.28545} & \multirow{6}{*}{0.20407} \\
\hline 1 & Protection and Security & 0.60792 & & & \\
\hline 2 & Electrical installations & 0.92048 & & & \\
\hline 3 & Hydraulic facilities & 0.93956 & & & \\
\hline 4 & Telecommunication facilities & 0.75963 & & & \\
\hline 5 & Organisation of the environment & 0.62631 & & & \\
\hline & Dimension 2 & & \multirow{6}{*}{2.86218} & \multirow{6}{*}{3.18651} & \multirow{6}{*}{0.15174} \\
\hline 6 & Thermal comfort & 0.82789 & & & \\
\hline 7 & Acoustic comfort & 0.93911 & & & \\
\hline 8 & Internal air quality & 0.57187 & & & \\
\hline 9 & Satisfaction of residents & 0.50394 & & & \\
\hline 10 & Structural durability & 0.54847 & & & \\
\hline & Dimension 3 & & \multirow{3}{*}{2.17846} & \multirow{3}{*}{1.99576} & \multirow{3}{*}{0.09504} \\
\hline 11 & Training of residents & 0.79695 & & & \\
\hline 12 & Facility management by residents & 0.76245 & & & \\
\hline & Dimension 4 & & \multirow{4}{*}{1.63946} & \multirow{4}{*}{1.63471} & \multirow{4}{*}{0.07784} \\
\hline 13 & Sealings & 0.51175 & & & \\
\hline 14 & Space control & 0.56134 & & & \\
\hline 15 & Building documentation & 0.65918 & & & \\
\hline & Dimension 5 & & \multirow{5}{*}{1.30687} & \multirow{5}{*}{3.04992} & \multirow{5}{*}{0.14523} \\
\hline 16 & Waste management I & 0.7972 & & & \\
\hline 17 & Waste Management II & 0.86144 & & & \\
\hline 18 & Costs & 0.54825 & & & \\
\hline 19 & Physical appearance & 0.59654 & & & \\
\hline & Dimension 6 & & \multirow{3}{*}{1.08452} & \multirow{3}{*}{1.47214} & \multirow{3}{*}{0.0701} \\
\hline 20 & Visual comfort & 0.73293 & & & \\
\hline 21 & Maintenance & -0.5504 & & & \\
\hline
\end{tabular}

\section{Validation of sub-criteria}

In order to validate the identified sub-criteria (Table 1), a Delphi was performed with the group of specialists. Therefore, six experts were selected considering two criteria: work experience in the area of interest and willingness to participate in the study. Table 4 shows the profile of the specialists.

The activity began with six experts, but throughout the second round one of the experts left the study. Thus, the next rounds took place with the other five participants. The participant who left the survey was identified as F.

Delphi had four rounds until it reached consensus among experts. As a result, 41 sub-criteria were validated, i.e., from the 79 sub-criteria, 41 were identified as useful to evaluate the performance of LWF buildings. In addition, the selection of the 41 sub-criteria resulted in the inclusion of 19 criteria. The result can be seen in Table 5 .

In addition, 21 criteria had been validated so far, but with the validation of sub-criteria, 2 criteria ("space control" and "waste management") had all the sub-criteria eliminated, and therefore were also eliminated. Thus, the factor analysis was performed a second time, now with the 19 criteria in order to regroup them.

For this second factorial analysis, the obtained KMO was 0.6664 , which confers the adequacy, and the Barlett test presented a level of significance of 0.000 , showing that there is a correlation between the criteria. In addition, Varimax rotation was also performed again to optimise the criteria organisation. The final result of the factorial analysis can be seen in Table 6. 
Table 4 - Profile of the experts who participated in the Delphi technique

\begin{tabular}{c|l|c|l}
\hline Identification & \multicolumn{1}{|c|}{ Occupation } & $\begin{array}{c}\text { Time working } \\
\text { with LWF }\end{array}$ & \multicolumn{1}{|c}{ Qualification } \\
\hline A & Construction company & Since 2010 & Master's in Environmental Engineering \\
\hline B & $\begin{array}{l}\text { Syndicate of the civil } \\
\text { construction }\end{array}$ & Since 2008 & Economist and Civil Engineer \\
\hline C & $\begin{array}{l}\text { Association of forestry- } \\
\text { based companies }\end{array}$ & Since 2009 & Doctor of Civil Engineering \\
\hline D & Academic researcher & Since 2010 & Doctor of Civil Engineering \\
\hline E & $\begin{array}{l}\text { Company of accessories } \\
\text { for LWF houses }\end{array}$ & Since 2013 & Industrial Engineer Lumberjack \\
\hline F & Academic researcher & Since 2008 & Postdoctoral fellow in Sustainable Buildings \\
\hline
\end{tabular}

Table 5 - Validated criteria and sub-criteria

\begin{tabular}{|c|c|}
\hline CRITERIA & SUB-CRITERIA \\
\hline \multirow{2}{*}{ Thermal comfort } & Internal temperature of the environment \\
\hline & Thermal variation of temperature (4 seasons/winter-summer) \\
\hline \multirow{2}{*}{ Acoustic comfort } & Internal noise level \\
\hline & External noise level (neighbours, neighbourhood, street, etc.) \\
\hline Visual comfort & Natural lighting \\
\hline \multirow{2}{*}{ Internal air quality } & Air circulation (ventilation) \\
\hline & Air humidity \\
\hline \multirow{3}{*}{ Protection and security } & Fire safety \\
\hline & Protection against harmful micro-organisms, insects and animals \\
\hline & Structural strength safety (walls) \\
\hline \multirow{4}{*}{ Satisfaction of residents } & Life and Real Estate Security \\
\hline & Feeling of "belonging to the environment" \\
\hline & Feeling of "well-being" \\
\hline & Productivity and performance \\
\hline \multirow{2}{*}{ Structural Durability } & Internal surfaces of the enterprise (cracks, fissures, holes, etc.) \\
\hline & External surfaces of the enterprise (cracks, cracks, holes, etc.) \\
\hline \multirow{2}{*}{ Maintenance } & Preventive of the internal surfaces of the development \\
\hline & Preventive of the external surfaces of the development \\
\hline \multirow[b]{2}{*}{ Electrical installations } & Ease of access for electrical components (sockets and connectors) \\
\hline & $\begin{array}{l}\text { Cleaning and safety components of electrical installations (sockets and } \\
\text { connectors) }\end{array}$ \\
\hline \multirow{2}{*}{ Hydraulic facilities } & Ease of access to hydraulic mechanisms \\
\hline & Cleaning and security of internal and external Hydraulic facilities \\
\hline Telecommunication installations & Ease of access to telecommunications mechanisms (telephone, internet, etc.) \\
\hline \multirow[t]{2}{*}{ Organisation of the environment } & $\begin{array}{l}\text { Plan of preventive and continuous maintenance in all the installations } \\
\text { (electrical, hydraulic, thermal - if there are any, etc.) }\end{array}$ \\
\hline & Flexibility and adaptability \\
\hline \multirow{2}{*}{ Sealings } & Insulation (protection of air intake) \\
\hline & Water tightness \\
\hline \multirow{3}{*}{ Energy Efficiency } & Rainwater harvesting management \\
\hline & Renewable energy management (solar capture) \\
\hline & Management of polluting gases \\
\hline \multirow{2}{*}{ Costs } & Maintenance costs (materials, equipment, people) \\
\hline & Expected cost vs actual (water, electricity, gas, etc.) \\
\hline \multirow{2}{*}{ Physical appearance } & Quality of materials used in building \\
\hline & Maintaining the physical appearance of the building \\
\hline \multirow{3}{*}{ Building documentation } & Electrical, hydraulic, mechanical and thermal projects \\
\hline & Environmental plan (sustainability) \\
\hline & Maintenance plan \\
\hline Training for residents & Guide for residents \\
\hline \multirow{3}{*}{ Facility management by residents } & Continuous maintenance made by residents $(3,6,9,12$ months $)$ \\
\hline & Awareness Programs \\
\hline & Relation construction company vs Residents \\
\hline
\end{tabular}


Table 6 - Result of the factorial analysis for the 19 validated criteria

\begin{tabular}{|c|c|c|c|c|c|}
\hline Criteria & Dimension & $\begin{array}{c}\text { Factorial } \\
\text { weight }\end{array}$ & Eigenvalues & Variance & Cumulated \\
\hline & Dimension 1 & & \multirow{6}{*}{6} & \multirow{6}{*}{3.87} & \multirow{6}{*}{0.2} \\
\hline 1 & Protection and Security & 0.54 & & & \\
\hline 2 & Electrical installations & 0.91 & & & \\
\hline 3 & Hydraulic facilities & 0.91 & & & \\
\hline 4 & Telecommunication facilities & 0.83 & & & \\
\hline 5 & Organisation of the environment & 0.67 & & & \\
\hline & Dimension 2 & & \multirow{5}{*}{2.72} & \multirow{5}{*}{2.89} & \multirow{5}{*}{0.15} \\
\hline 6 & Thermal comfort & 0.85 & & & \\
\hline 7 & Acoustic comfort & 0.88 & & & \\
\hline 8 & Visual comfort & 0.56 & & & \\
\hline 9 & Internal air quality & 0.57 & & & \\
\hline & Dimension 3 & & \multirow{4}{*}{1.92} & \multirow{4}{*}{2.63} & \multirow{4}{*}{0.14} \\
\hline 10 & Building documentation & 0.65 & & & \\
\hline 11 & Training of residents & 0.79 & & & \\
\hline 12 & Facility management by residents & 0.82 & & & \\
\hline & Dimension 4 & & \multirow{4}{*}{1.51} & \multirow{4}{*}{2.12} & \multirow{4}{*}{0.11} \\
\hline 13 & Structural durability & 0.72 & & & \\
\hline 14 & Maintenance & 0.78 & & & \\
\hline 15 & Sealings & 0.56 & & & \\
\hline & Dimension 5 & & \multirow{5}{*}{1.31} & \multirow{5}{*}{1.95} & \multirow{5}{*}{0.1} \\
\hline 16 & Satisfaction of residents & 0.56 & & & \\
\hline 17 & Energy efficiency & 0.67 & & & \\
\hline 18 & Costs & 0.73 & & & \\
\hline 19 & Physical appearance & 0.53 & & & \\
\hline
\end{tabular}

\section{Generating weights}

The last step of the method was to establish weights for the validated sub-criteria, which was done using a questionnaire. In order to validate the reliability of this questionnaire, Cronbach's alpha coefficient was calculated. The identified result was in the range of 0.9232 , which gives satisfactory reliability. Table 7 presents the "weighted average" of each validated sub-criteria, "ranking" (1st to 41th), "wj" (weight of each sub-criteria) and "score" (weight score for each sub-criteria), as presented in "Method Research-Weight generation" the section.

The most important sub-criterion is water tightness, first in the ranking. The importance of the sub-criteria is consistent with reality as Brazil is a tropical country with high temperatures and humidity, which are favourable characteristics for the degradation of the main material used in LWF constructions. Thus, it is essential to comply with the requirements established by the documents that guide this system in Brazil. Such care with the material should be considered both during construction and throughout the service life. It is also worth noting that as wood is underexplored in the Brazilian construction sector, it is essential to raise awareness and teach users to preserve the material in order to maintain building performance.

The compilation also showed the dimensions that have the highest score, that is, those that have a greater relevance during the evaluation of the performance of an LWF building. Figure 3 graphically shows the percentage value of each dimension.

The dimension with the highest score is 4 as it has 68 points (39\%), which refers to criteria related to structural durability, maintenance and sealing. These criteria signal the need to preserve wood, the main component in LWF buildings. The maintenance by the users during service life and especially the adequate sealing of wood to avoid direct contact with water and xylophagous insects that can degrade the material is highly important.

The second highest score is dimension 2, with 42 points (25\%), which is one that measures the comfort of the building. This result is consistent with the literature. Several studies indicate the analysis of thermal, acoustic, visual and air quality comfort of buildings as the main factors to be studied in BPE surveys.

566 Sotsek, N. C.; Leitner, D. S.; Santos, B. L.; Messias, J. dos S. N.; Santos, A. de P. L. 
The score established in this study shows the most critical criteria during a performance analysis of a LWF building in tropical countries. It also highlights more care for wood, which has a different composition from the Nordic countries and suffers greater degradation due to the climatic conditions. It is worth mentioning that the LWF system is still very recent in these countries and, therefore initiatives of teaching and awareness of the users must be taken into account to maintain the quality and performance of these buildings. Such work could be included in construction companies' activities. This consideration was highlighted in Dimension 3 of this study, which emphasised the importance of training, adequate documentation and management of facilities by users to maintain the buildings.

Table 7 - Evaluation of the performance evaluation method of an LWF building in Brazil (Continues...)

\begin{tabular}{|c|c|c|c|c|c|c|c|c|c|}
\hline \multicolumn{10}{|c|}{ DATA COMPILATION } \\
\hline $\begin{array}{l}\text { Criteria for performance analysis of } \\
\text { buildings in Light Wood Frame (LWF) }\end{array}$ & \multicolumn{5}{|c|}{ WEIGHTS } & $\begin{array}{l}\text { Weighted } \\
\text { Average }\end{array}$ & Ranking & $\mathbf{w j}$ & $\begin{array}{l}\text { Score } \\
(\mathbf{s j})\end{array}$ \\
\hline 1. DIMENSION 1 & \multicolumn{5}{|c|}{ RESPONDENTS } & & & & \\
\hline 1.1 PROTECTION AND SECURITY & 1 & 2 & 3 & 4 & 5 & & & & \\
\hline 1.1.1 Fire safety & & 1 & 6 & 8 & 5 & 4 & 22 & 0 & 2 \\
\hline $\begin{array}{l}\text { 1.1.2 Protection against harmful micro- } \\
\text { organisms, insects and animals }\end{array}$ & & 1 & 8 & 6 & 8 & 4 & 18 & 0 & 2 \\
\hline 1.1.3 Structural strength safety (walls) & & 1 & 6 & 4 & 12 & 4 & 8 & 0 & 5 \\
\hline 1.2 ELECTRICAL INSTALLATIONS & 1 & 2 & 3 & 4 & 5 & & & & \\
\hline $\begin{array}{l}\text { 1.2.1 Ease of access for electrical components } \\
\text { (sockets and connectors) }\end{array}$ & & 4 & 7 & 4 & 8 & 4 & 27 & 0 & 2 \\
\hline $\begin{array}{l}\text { 1.2.2 Cleaning and safety components of } \\
\text { electrical installations (sockets and } \\
\text { connectors) }\end{array}$ & & 5 & 4 & 8 & 6 & 4 & 29 & 0 & 1 \\
\hline 1.3 HYDRAULIC FACILITIES & 1 & 2 & 3 & 4 & 5 & & & & \\
\hline 1.3.1 Ease of access to hydraulic mechanisms & & 3 & 7 & 6 & 7 & 4 & 25 & 0 & 2 \\
\hline $\begin{array}{l}\text { 1.3.2 Cleaning and security of internal and } \\
\text { external hydraulic facilities }\end{array}$ & 1 & 4 & 3 & 9 & 6 & 4 & 29 & 0 & 1 \\
\hline $\begin{array}{l}1.4 \text { TELECOMMUNICATION } \\
\text { INSTALLATIONS }\end{array}$ & 1 & 2 & 3 & 4 & 5 & & & & \\
\hline $\begin{array}{l}\text { 1.4.1 Ease of access to telecommunication } \\
\text { mechanisms (telephone, internet, among } \\
\text { others) }\end{array}$ & & 3 & 10 & 3 & 7 & 4 & 31 & 0 & 1 \\
\hline $\begin{array}{l}\text { 1.5 ORGANISATION OF THE } \\
\text { ENVIRONMENT }\end{array}$ & 1 & 2 & 3 & 4 & 5 & & & & \\
\hline $\begin{array}{l}\text { 1.5.1 Plan of preventive and continuous } \\
\text { maintenance in all the installations (electrical, } \\
\text { hydraulic, thermal, if there are any, among } \\
\text { others) }\end{array}$ & & & 5 & 12 & 6 & 4 & 12 & 0 & 3 \\
\hline 1.5.2 Flexibility and adaptability & & 6 & 4 & 6 & 5 & 3 & 35 & 0 & 1 \\
\hline 2. DIMENSION 2 & $\mathrm{RE}$ & $\mathrm{SP}$ & DND & ENT & & & & & \\
\hline 2.1 THERMAL COMFORT & 1 & 2 & 3 & 4 & 5 & & & & \\
\hline 2.1.1 Internal ambient temperature & & & 3 & 7 & 13 & 4 & 2 & 0 & 20 \\
\hline $\begin{array}{l}\text { 2.1.2 Thermal variation ( } 4 \text { seasons/winter- } \\
\text { summer) }\end{array}$ & & 1 & 3 & 7 & 12 & 4 & 4 & 0 & 10 \\
\hline 2.2 ACOUSTIC COMFORT & 1 & 2 & 3 & 4 & 5 & & & & 0 \\
\hline 2.2.1 Internal noise level & & 1 & 7 & 6 & 9 & 4 & 15 & 0 & 3 \\
\hline $\begin{array}{l}\text { 2.2.2 Level of external noise (neighbours, } \\
\text { neighbourhood, street among others) }\end{array}$ & 1 & 1 & 5 & 6 & 10 & 4 & 15 & 0 & 3 \\
\hline 2.3 VISUAL COMFORT & 1 & 2 & 3 & 4 & 5 & & & & \\
\hline 2.3.1 Natural lighting & 2 & & 10 & 9 & 2 & 3 & 40 & 0 & 1 \\
\hline 2.4 AIR QUALITY & 1 & 2 & 3 & 4 & 5 & & & & 0 \\
\hline 2.4.1 Circulation of air & & 1 & 7 & 5 & 10 & 4 & 12 & 0 & 3 \\
\hline 2.4.2 Air humidity & & & 8 & 9 & 6 & 4 & 18 & 0 & 2 \\
\hline
\end{tabular}


Table 7 - Evaluation of the performance evaluation method of an LWF building in Brazil (continued)

\begin{tabular}{|c|c|c|c|c|c|c|c|c|c|}
\hline 3. DIMENSION 3 & \multicolumn{5}{|c|}{ RESPONDENTS } & & & & \\
\hline 3.1 BUILDING DOCUMENTATION & 1 & 2 & 3 & 4 & 5 & & & & \\
\hline $\begin{array}{l}\text { 3.1.1 Electrical, hydraulic, } \\
\text { telecommunications, structural, thermal (if } \\
\text { any) }\end{array}$ & & 1 & 5 & 9 & 8 & 4 & 12 & 0 & 3 \\
\hline 3.1.2 Environmental plan (sustainability) & & 3 & 9 & 7 & 4 & 4 & 34 & 0 & 1 \\
\hline 3.1.3 Maintenance plan & & 1 & 9 & 8 & 5 & 4 & 25 & 0 & 2 \\
\hline 3.2 TRAINING & 1 & 2 & 3 & 4 & 5 & & & & \\
\hline 3.2.1 Residents' Guide & & 1 & 12 & 9 & 1 & 3 & 37 & 0 & 1 \\
\hline 3.3 MANAGEMENT & 1 & 2 & 3 & 4 & 5 & & & & \\
\hline 3.3.1 Ongoing maintenance by residents & 1 & & 10 & 8 & 4 & 4 & 31 & 0 & 1 \\
\hline 3.3.2 Awareness program & 1 & 1 & 11 & 7 & 3 & 3 & 37 & 0 & 1 \\
\hline 3.3.3 Relation builder vs residents & 2 & & 11 & 7 & 3 & 3 & 40 & 0 & 1 \\
\hline 4. DIMENSION 4 & \multicolumn{5}{|c|}{ RESPONDENTS } & & & & \\
\hline 4.1 STRUCTURAL DURABILITY & 1 & 2 & 3 & 4 & 5 & & & & \\
\hline $\begin{array}{l}\text { 4.1.1 Internal surfaces of the enterprise } \\
\text { (Cracks, fissures, holes, etc.) }\end{array}$ & & & 4 & 10 & 9 & 4 & 6 & 0 & 7 \\
\hline $\begin{array}{l}\text { 4.1.2 External surfaces of the enterprise } \\
\text { (Cracks, fissures, holes, etc.) }\end{array}$ & & & 5 & 10 & 8 & 4 & 9 & 0 & 4 \\
\hline 4.2 MAINTENANCE & 1 & 2 & 3 & 4 & 5 & & & & \\
\hline $\begin{array}{l}\text { 4.2.1 Preventive of the internal surfaces of the } \\
\text { enterprise }\end{array}$ & & 4 & 4 & 12 & 3 & 4 & 31 & 0 & 1 \\
\hline $\begin{array}{l}\text { 4.2.2 Preventive of the external surfaces of the } \\
\text { project }\end{array}$ & & & 7 & 12 & 3 & 4 & 23 & 0 & 2 \\
\hline 4.3 SEALINGS & 1 & 2 & 3 & 4 & 5 & & & & \\
\hline 4.3.1 Insulation (protection of air intake) & & & 3 & 9 & 11 & 4 & 3 & 0 & 13 \\
\hline 4.3.2 Water tightness & & & 1 & 6 & 16 & 5 & 1 & 0 & 40 \\
\hline 5. DIMENSION 5 & \multicolumn{5}{|c|}{ RESPONDENTS } & & & & \\
\hline 5.1 SATISFACTION OF THE DWELLERS & 1 & 2 & 3 & 4 & 5 & & & & \\
\hline 5.1.1 Security of life and real estate & & & 5 & 7 & 11 & 4 & 5 & 0 & 8 \\
\hline $\begin{array}{l}\text { 5.1.2 Feeling of "belonging to the } \\
\text { environment" }\end{array}$ & 1 & 1 & 7 & 9 & 5 & 4 & 27 & 0 & 2 \\
\hline 5.1.3 Feeling of "well-being"” & & & 4 & 11 & 8 & 4 & 8 & 0 & 5 \\
\hline 5.1.4 Productivity and Performance & & 2 & 5 & 10 & 6 & 4 & 20 & 0 & 2 \\
\hline 5.2 ENERGY EFFICIENCY & 1 & 2 & 3 & 4 & 5 & & & & \\
\hline 5.2.1 Rainwater harvesting management & 1 & 2 & 10 & 6 & 3 & 3 & 41 & 0 & 1 \\
\hline $\begin{array}{l}\text { 5.2.2 Renewable energy management (solar } \\
\text { capture) }\end{array}$ & 1 & 2 & 8 & 9 & 2 & 3 & 38 & 0 & 1 \\
\hline 5.2.3 Management of polluting gases & & 2 & 11 & 5 & 5 & 4 & 33 & 0 & 1 \\
\hline 5.3 COSTS & 1 & 2 & 3 & 4 & 5 & & & & \\
\hline $\begin{array}{l}\text { 5.3.1 Maintenance costs (materials, } \\
\text { equipment, people) }\end{array}$ & & 3 & 2 & 12 & 5 & 4 & 21 & 0 & 2 \\
\hline $\begin{array}{l}\text { 5.3.2 Expected cost } \mathrm{X} \text { actual (water, } \\
\text { electricity, gas, etc.) }\end{array}$ & & 4 & 2 & 10 & 7 & 4 & 20 & 0 & 2 \\
\hline 5.4 PHYSICAL APPEARANCE & 1 & 2 & 3 & 4 & 5 & & & & \\
\hline 5.4.1 Quality of materials used in building & & 2 & 4 & 7 & 9 & 4 & 10 & 0 & 4 \\
\hline $\begin{array}{l}5.4 .2 \text { Maintaining the physical appearance of } \\
\text { the building }\end{array}$ & & 1 & 6 & 8 & 7 & 4 & 16 & 0 & 3 \\
\hline
\end{tabular}

568 Sotsek, N. C.; Leitner, D. S.; Santos, B. L.; Messias, J. dos S. N.; Santos, A. de P. L. 
Figure 3 - Percentage value of each dimension of LWF building performance evaluation method

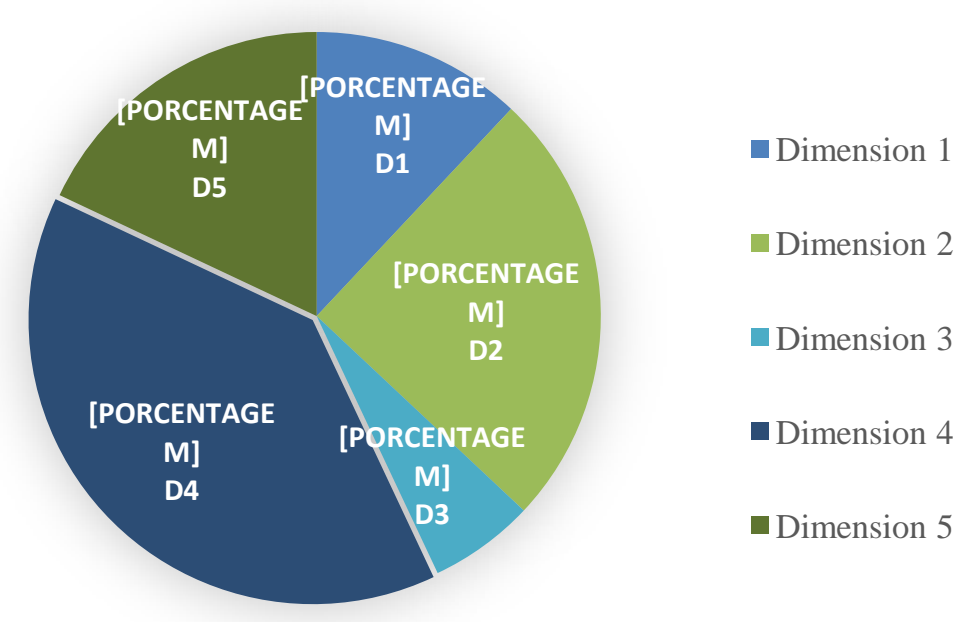

Table 8 - Score elaboration for BPE evaluation

\begin{tabular}{l|l}
\hline \multicolumn{1}{c|}{ Score } & \multicolumn{1}{c}{ Performance reached } \\
\hline Less than $50 \%$ & Minimal performance \\
\hline $60-75 \%$ & Average performance \\
\hline $75 \%$ and above & High performance \\
\hline
\end{tabular}

Then, with a total score of 173 points, a score was established that could be used as an evaluation mechanism for these buildings. That is, through the sub-criteria evaluated, the buildings may present a performance value for each of the 5 Dimensions established. This score was elaborated considering the percentage of the building covered, as well as the work of Hong (2008) and the Green Globe certification specifications. The building that meets $50 \%$ of the criteria will be considered a building with minimum performance; $51-75 \%$ average performance and above $76 \%$ high performance (Table 8 ).

The proposal in this work is not to create a certification, but rather to present a structural proposal of how to map the performance to serve as a base to help organisations that seek to improve the quality of buildings.

\section{Conclusions}

This study presented a method of evaluating light wood frame buildings in Latin America. The designed method established a table with 5 dimensions, 19 criteria and 41 sub-criteria, which were validated by specialists and presented the following weights in sequence: 21 (dimension 1), 42 (dimension 2), 11 (dimension 3), 68 (dimension 4) and 31 (dimension 5) out of a total of 173 points. From these, $81 \%$ refer to dimensions 4 and 2 which consider the following elements: structural durability, maintenance and sealing, in dimension 4 and dimension 2, thermal comfort, acoustic comfort, visual comfort and air quality.

This study was applied in Brazil and professionals who work directly with LWF construction system participated in it. The result of this study provides good orientation for those who want to evaluate the performance of light wood frame buildings, a system still considered innovative for Latin American countries. The scoring structure was developed taking several parameters into consideration in order to approach the method in an objective and holistic way seeking to highlight essential factors for construction performance. This study may contribute to the diffusion of the construction system in the country and may help managers involved in the maintenance of these constructions to obtain high user satisfaction.

\section{References}

ASSOCIAÇÃO BRASILEIRA DE NORMAS TÉCNICAS. NBR 15575: edificações habitacionais: desempenho. Rio de Janeiro, 2013.

AMERICAN SOCIETY FOR TESTING AND MATERIALS. Annual Book of ASTM Standards, 2017. 
BLACHERE, G. Savoir bâtir, habitabilité-durabilité et économie des bâtiments. Paris : Edition Eyrolles, 1974.

BONNATO, F. S; MIRON, L. I. G; FORMOSO, C. T. Avaliação de empreendimentos habitacionais de interesse social com base na hierarquia de valor percebido pelo usuário. Ambiente Construído, Porto Alegre, v. 11, n. 1, p. 67-83, jan./mar. 2011.

BORGES, C. A. D. M. O conceito de desempenho de edificações e a sua importância para o setor da construção civil no Brasil. Tese (Doutorado em Engenharia Civil)- Escola de Engenharia, Universidade de São Paulo, São Paulo, 2008.

BUREAU OF INDIAN STANDARDS. National building code of India (NBC) 2016. 2016. Available: http://bis.org.in/sf/nbc.htm. Access: 15 fev. 2020.

CANDIDO, C. et al. BOSSA: a multidimensional post-occupancy evaluation tool. Building Research \& Information, v. 44, n. 2, p. 214-228, 2016.

COELHO, G. M. Prospecção tecnológica: metodologias e experiências nacionais e internacionais. Projeto CTPetro Tendências Tecnológicas: Nota Técnica, 14, 2003.

DEPARTMENT BUILDING HOUSING. Using the product assurance framework to support building code compliance - a guide for manufacturers and suppliers of building product. Wellington: Department of Building and Housing, 2010.

DRESCH, A.; LACERDA, D. P.; JÚNIOR, J. A. V. A. Design science research: método de pesquisa para avanço da ciência e tecnologia. Porto Alegre: Bookman, 2015.

ELYNA MYEDA, N.; NIZAM KAMARUZZAMAN, S.; PITT, M. Measuring the performance of office buildings maintenance management in Malaysia. Journal of Facilities Management, v. 9, n. 3, p. 181-199, 2011.

FINCH, E. (ed.). Facilities change management. West Sussex: Wiley-Blackwell, 2011.

GOPIKRISHNAN, S.; TOPKAR, V. M. Attributes and descriptors for building performance evaluation. HBRC journal, v. 13, n. 3, p. 291-296, 2017.

HASHIM, A. E.; AKSAH, H.; SAID, S. Y. Functional assessment through post occupancy review on refurbished historical public building in Kuala Lumpur. Procedia-Social and Behavioral Sciences, v. 68, p. 330-340, 2012.

HONG, Y. Environmental assessment criteria and protocols for residential developments. Singapore, 2008. Ms Thesis, National University of Singapore, Singapore.

IBEM, E. O. et al. Performance evaluation of residential buildings in public housing estates in Ogun State, Nigeria: Users' satisfaction perspective. Frontiers of Architectural Research, v. 2, n. 2, p. 178-190, 2013.

INSTITUTO DE PESQUISA ECONÔMICA APLICADA. Habitação. In: IPEA. Políticas Sociais: acompanhamento e análise, 2007.v. 14, p. 279-302.

INTERNATIONAL ORGANIZATION FOR STANDARDIZATION. ISO 15928: houses: description of performance. Geneve, 2015.

INTERNATIONAL ORGANIZATION FOR STANDARDIZATION. ISO 19208: framework for specifying performance in buildings. Geneve, 2016.

INTERNATIONAL ORGANIZATION FOR STANDARDIZATION. ISO 6241: performance standards in building: principles for their preparation and factors to be considered. Geneve, 1984.

KHAIR, N. et al. Post occupancy evaluation of physical environment in public low-cost housing. Jurnal Teknologi, v. 75, n. 10, p. 155-162, 2015.

KHALIL, N.; KAMARUZZAMAN, S. N.; BAHARUM, M. R. Ranking the indicators of building performance and the users' risk via Analytical Hierarchy Process (AHP): case of Malaysia. Ecological indicators, v. 71, p. 567-576, 2016.

KHAN, S.; KOTHARKAR, R. Performance evaluation of school environs: Evolving an appropriate methodology building. Procedia-Social and Behavioral Sciences, v. 50, p. 479-491, 2012. 
LAI, J. H. K.; MAN, C. S. Developing a performance evaluation scheme for engineering facilities in commercial buildings: state-of-the-art review. International Journal of Strategic Property Management, v. 21, n. 1, p. 41-57, 2017.

LAVY, S.; GARCIA, J. A.; DIXIT, M. K. Establishment of KPIs for facility performance measurement: review of literature. Facilities, v. 28, n. 9/10, p. 440-464, 2010.

LINSTONE, H. A.; TUROFF, M. The Delphi Method: technique and application. University of Southern California, 2002.

MEIR, I. A. et al. Post-occupancy evaluation: An inevitable step toward sustainability. Advances in Building Energy Research, v. 3, n. 1, p. 189-219, 2009.

MINISTÉRIO DAS CIDADES. DATec No 020-C. "Sistema estruturado em peças leves de madeira maciça serrada - Tecverde (tipo light wood framing)", 2017 a.

MINISTÉRIO DAS CIDADES. SINAT No 005 - Revisão 2. Sistemas construtivos estruturados em peças leves de madeira maciça serrada, com fechamentos em chapas (Sistemas leves tipo "Light Wood Framing"), $2017 b$.

MINISTERIO DE VIVIENDA. Código Técnico de la Edificación (CTE): partes I y II. 2006.

MOHIT, M. A.; AZIM, M. Assessment of residential satisfaction with public housing in Hulhumale', Maldives. Procedia-Social and Behavioral Sciences, v. 50, p. 756-770, 2012.

MOHIT, M. A.; NAZYDDAH, N. Social housing programme of Selangor Zakat Board of Malaysia and housing satisfaction. Journal of Housing and the Built environment, v. 26, n. 2, p. 143-164, 2011.

NAZEER, S. F.; DE SILVA, N. TBPE scoring framework for tropical buildings. Built Environment Project and Asset Management, v. 6, n. 2, p. 174-186, 2016.

NIK-MAT, N. E. M.; KAMARUZZAMAN, S. N.; PITT, M. Assessing the maintenance aspect of facilities management through a performance measurement system: a Malaysian case study. Procedia Engineering, v. 20, p. 329-338, 2011.

NURIZAN, Y.; HASHIM, A. H. Perumahan dan Kediaman (Housing and residential). Malaysia: Universiti Putra Malaysia, 2001.

PALLANT, J. SPSS Survival manual: a step by step guide to data analysis using SPSS. New South Wales: Allen \& Unwin, 2011.

PESTANA, M. H.; GAGEIRO, J. N. Análise de dados para ciências sociais: a complementariedade do SPSS. 4. ed. Lisboa: Editora Silabo, 2005.

PREISER, W. F. Post-occupancy evaluation: how to make buildings work better. Facilities, v. 13, n. 11, p. 19-28, 1995.

QUEENSLAND GOVERNMENT. Building Asset Performance Framework (BAPF). Queensland Department of Housing and Public Works. 2008. Available: http://www.hpw.qld.gov.au/SiteCollectionDocuments/BAPF.pdf. Access: 15 jan. 2020.

RIRATANAPHONG, C.; VAN DER VOORDT, T. Measuring the added value of workplace change: performance measurement in theory and practice. Facilities, v. 33, n. 11/12, p. 773-792, 2015.

STEINKE, C.; WEBSTER, L.; FONTAINE, M. Evaluating building performance in healthcare facilities: an organizational perspective. HERD: Health Environments Research \& Design Journal, v. 3, n. 2, p. 6383, 2010.

STØRE-VALEN, M.; LOHNE, J. Analysis of assessment methodologies suitable for building performance.Facilities, v. 34, n. 13/14, p. 726-747, 2016.

TALIB, Y.; YANG, R. J.; RAJAGOPALAN, P. Evaluation of building performance for strategic facilities management in healthcare: a case study of a public hospital in Australia. Facilities, v. 31, n. 13/14, p. 681$701,2013$.

TRIOLA, M. F. Introdução à estatística. 7. ed. Rio de Janeiro: LTC-Livros Técnicos e Científicos, 1999.

VILLA, S. B.; ORNSTEIN, S. W. Qualidade ambiental na habitação: avaliação pós-ocupação. São Paulo: Oficina de Textos, 400 p, 2013. 
VISCHER, J. C. Towards a user-centred theory of the built environment. Building Research \& Information, v. 36, n. 3, p. 231-240, 2008.

\title{
Acknowlegments
}

The authors are grateful for the funds received from Capes (Coordination of Improvement of Higher Education Personnel, Brazil) for the development of this research.

\section{Nicolle Christine Sotsek}

Programa de Pós-Graduação em Construção Civil | Universidade Federal do Paraná | Av. Cel. Franscico H. dos Santos, Jardim das Américas, Centro Politécnico | Curitiba - PR - Brasil | CEP 81531-990 | Tel.: (41) 3361-3110 | E-mail: nicolleramos@ufpr.br

\section{Drielle Sanchez Leitner}

Programa de Pós-Graduação em Construção Civil | Universidade Federal do Paraná | E-mail: drielle.dsl@gmail.com

\section{Bruno Lacerda Santos}

Graduando em Engenharia Civil| Universidade Federal do Paraná | Tel.: (41) 3361-3044 | E-mail: brunolacerda99@gmail.com

\section{Janilce dos Santos Negrão Messias}

Programa de Pós Graduação em Construção Civil | Universidade Federal do Paraná | E-mail: janilce@ufpr.br

Adriana de Paula Lacerda Santos

Programa de Pós Graduação em Construção Civil | Universidade Federal do Paraná | E-mail: adriana.pls1@gmail.com

\author{
Ambiente Construído \\ Revista da Associação Nacional de Tecnologia do Ambiente Construído \\ Av. Osvaldo Aranha, $99-3^{\circ}$ andar, Centro \\ Porto Alegre - RS - Brasil \\ CEP 90035-190 \\ Telefone: +55 (51) 3308-4084 \\ Fax: +55 (51) 3308-4054 \\ www.seer.ufrgs.br/ambienteconstruido \\ E-mail: ambienteconstruido@ufrgs.br
}

(c) (i) This is an open-access article distributed under the terms of the Creative Commons Attribution License. 